\title{
РЕВОЛЮЦИИ
}

Спиридонов В.В.

DOI: 10.7256/2305-560X.2014.4.11924

\section{РОЛЬ МЕЖДУНАРОДНЫХ РЕЙТИНГОВЫХ АГЕНТСТВ В РЕАЛИЗАЦИИ ЭКОНОМИЧЕСКИХ САНКЦИЙ ПРОТИВ РОССИИ В СВЕТЕ СОБЫТИЙ НА УКРАИНЕ}

\begin{abstract}
Аннотация: После того, как Крымский полуостров, по результатам народного рефререндума, стал частью России, некоторые страны западного мира открыто заговорили о политических и экономических санкциях против Российской Федерации. В частности, одной из мер против России стало явление резкого понижения прогнозов по кредитным рейтингам России. Так, крупнейшие международные рейтинговые агентства снизили прогнозы по кредитному рейтингу отечественных банков и крупных российских компаний, сделав это синхронно и согласованно, как по команде. Насколько болезненным для России является этот шаг рейтинговых агентств, какие последствия могут ожидать Россию и мировое сообщество в этой связи, посвящена настоящая работа. Как отмечает А.В. Манойло, "политические санкции - это, прежде всего, волна морального укора и осуждения, которая должна обрушиться на Россию и заставить ее испытывать чувство стыда". Похоже, что не только от содеянного, а вообще - нормальным состоянием России должен стать стыд.
\end{abstract}

Ключевые слова: международные отношения, внешняя политика, Украина, Крым, рейтинг, рейтинговое агенство, государство, конфликт, санкции, Россия.

$\mathrm{B}$ России «с иронией воспринимают попытки США, известных своей двойной моралью, выступить вселенским морализатором, ревнителем и хранителем нравственных канонов" ${ }^{1}$.Может быть поэтому политических санкций по отношению к России оказалось мало политический бомонд США выдвинул идею экономических санкций. Одна из таких санкций исключение России из "Большой восьмёрки" экономически развитых государств. Кстати сразу возникает вопрос: после этого исключения жители России легли спать в экономически развитой, а проснулись в экономически отсталой стране? Как справедливо замечено в работе ${ }^{2}$, “...в результате американские политики сами себя выставляют на посмешище”. Причём, вовлекая в политические игрища экономический блок, США, очевидно, не задумываются о том, что тем

\footnotetext{
1 Манойло А.В. Президент Обама и его Континентальная блокада России // NB: Международные отношения. - 2014. № 4. - C.1-6. DOI: 10.7256/2306-4226.2014.4.11563. URL: http://e-notabene.ru/wi/article_11563.html

2 Манойло А.В. Президент Обама и его Континентальная блокада России // NB: Международные отношения. - 2014. № 4. - C.1-6. DOI: 10.7256/2306-4226.2014.4.11563. URL: http://e-notabene.ru/wi/article_11563.html
}

самым решение насущных мировых экономических проблем, в том числе, и американских проблем, отодвигается на неопределённое “потом".

Напомним, что в июне 2013 года в СанктПетербурге прошёл форум двадцати экономически развитых государств. Россия 1 декабря 2012 года приняла годовые полномочия председателя в G-20. Группа двадцати была создана как площадка для плодотворного общения ведущих промышленно развитых стран и стран с развивающейся экономикой. Цель Форума - стремление к международной экономической стабильности, обеспечение устойчивого экономического роста, предотвращение новых финансовых кризисов и шоков. “Большая двадцатка” значительно расширяет формат по сравнению с тем охватом сотрудничества, который имеет место в рамках наиболее влиятельных экономических сил $G$-8. Как заявил Президент России по итогам форума, “...лидерам 19 стран и руководству Евросоюза удалось ...продвинуться в решении мировых экономических проблем, ...удалось выйти на многие важные практические решения как для международного сообщества, так и в интересах российской экономики, фактически по каждому направлению предложить свой план действий, направленный на поиск и стимулирование но- 
вых источников роста"3. Теперь же, во многом благодаря США, мировое экономическое сообщество вынуждено не заниматься улучшением экономического климата и развития, а участвовать в санкциях против России. Таким образом, получается, что летние договорённости в рамках “Большой двадцатки” откладываются?

В “экономическую войну” начавшуюся против России одними из первых вступили рейтинговые агентства. Всего в мире насчитывается около 100 рейтинговых агентств, профессионально занимающихся определением рейтингов участников рынка. В мировом масштабе особым авторитетом и весом пользуются лишь единицы из них. Какова же цель деятельности рейтинговых агентств? Ответом на это вопрос, по мнению автора, является коммерческая деятельность, по представлению услуг, связанных с анализом и оценкой платёжеспособности тех или иных эмитентов, долговых обязательств, качества корпоративного управления, качества управления активами и выставления по результатам исследования оценки- кредитного рейтинга. Кредитным рейтингом, таким образом, является показатель платежеспособности заёмщика. Подобным заёмщиком может выступать компания, банк, транснациональная корпорация или государство.

Итак, ключевой результат деятельности рейтинговых агентств- оценка платёжеспособности или кредитный рейтинг, отражающий риск невыплаты по тому или иному долговому обязательству. Важно отметить, что кредитный рейтинг влияет на величину процентной ставки, на стоимость и доходность долговых обязательств; кроме того, более высокий рейтинг соответствует меньшему риску невыплаты 4 .

Итак, фактически сразу же после озвучивания темы экономических санкций против России, “...два крупных мировых рейтинговых агентства понизили прогноз суверенного рейтинга России со «стабильного» на «негативный». Главной причиной решения стала политическая неопределенность вокруг крымского кризиса" ${ }^{\text {. }}$

Хотелось бы сразу успокоить: понижение прогноза по рейтингу не означает понижения самого рейтинга. Произошло только понижение прогноза, а кредитный рейтинг Российской федерации под-

\footnotetext{
3 http://ru.wikinews.org

4 http://finmarket.ru

5 http://www.otr-online.ru
}

твержден указанными рейтинговыми агентствами на уровне “ВВВ". Важно отметить, что данный рейтинг соответствует среднему по надежности, бумаги эмитента с таким рейтингом считаются привлекательными для инвесторов.

В таблице 1 представлены некоторые макроэкономические показатели и сравнение их с кредитным рейтингом России за период с 2011 по 2014 г.

Таблица 1.

\section{Макроэкономические показатели РФ, сравнение их с кредитным рейтингом за период с 2011 по 2014 г. $^{6}$}

\begin{tabular}{|l|c|c|c|c|}
\hline Год & $\mathbf{2 0 1 1}$ & $\mathbf{2 0 1 2}$ & $\mathbf{2 0 1 3}$ & $\mathbf{2 0 1 4}$ \\
\hline $\begin{array}{l}\text { Чистые иностранные } \\
\text { активы, \% ВВП }\end{array}$ & 23,5 & 24 & 22,3 & 22 \\
\hline $\begin{array}{l}\text { Государственный долг, } \\
\% \text { ВВП }\end{array}$ & 11,2 & 10 & 10,4 & 11 \\
\hline Рейтинг & & & & ВВВ \\
\hline
\end{tabular}

По данным агентства Fitch Ratings: fitch.com

Как следует из представленной таблицы, внешний долг России за период с 2011 по 2014 г. составляет в среднем 10,5 \% ВВП. Динамика изменения указанного параметра, очевидно, близка к долям процента. Также стабильной с точки зрения постоянства величины является и объём чистых иностранных активов (ЧИА) РФ, который составляет в среднем около 23\% ВВП за период исследования. Следует отметить, что по объёму золото- валютных резервов, входящих в состав ЧИА, Россия занимает пятое место в мире. Прибавим к этому положительное сальдо торгового баланса - превышение экспорта над импортом на 177 млрд. долл. по состоянию на 2013 г.

А теперь давайте совершим небольшое путешествие в страну на юге Европы - Грецию. Античные герои, тёплое море... Вместе с тем, годовой бюджет государства в течение многих лет был дефицитным, плохо структурированным. Доходная часть регулярно не исполнялась. Для покрытия дефицита Греция постоянно принимала на себя новые долговые обязательства. Это вело к росту чистой задолженности страны. Полная невозможность дальнейшего обслуживания государственного долга привела к падению кредитного рейтинга Греции. Нельзя не признать, что рейтинговые агентства совершенно объективно отражали ситуацию вокруг Греции. Долговым обязательствам государства предрекали уровень

6 По данным ЦБ РФ и Министерства финансов РФ: www. minfin.ru 
“бросовых”. Однако в случае Греции и Европейский союз, и мировое сообщество задумались о том, как спасти ситуацию, как поскорее экономически “вылечить" страну, попавшую в крайне затруднительное положение.

В случае России, которая является устойчивым в своём экономическом развитии государством, внимание привлекает не столько сам рейтинг страны, который остаётся неизменным, а шумиха и суета, поднимаемые для того, чтобы попытаться отвлечь инвесторов от неё. Ведь не случайно глава немецкой компании "Adidas" отметил о “непоправимых последствиям для их бизнеса" принятие экономических санкций к России ${ }^{[5]}$. Думаю, что для большинства инвесторов это является очевидным моментом. Кроме того, и Россия не остаётся в стороне. Ответным шагом российской стороны стало ускорение действий по уменьшению роли указанных агентств на территории РФ. Заместитель Председателя Правительства РФ Игорь Шувалов заявил, что Россия не будет зависеть от международных рейтингов, такую работу в настоящее время ведет Банк России.

«Работа эта проводится, она проводится давно, и, конечно, сейчас она будет ускорена и доведена до каких-то конкретных решений. Мы всецело зависеть от рейтинговых агентств, названия которых всем известны, не будем», - сказал Шувалов, выступая на заседании Совета Федерации ${ }^{7}$.

Вместе с тем, налицо конструктивная и взвешенная политика российской стороны. В частности, появилось предложение создать международное рейтинговое агентство, акционерами которого выступили бы государства-учредители. По мнению президента-председателя правления ВТБ А.Л.
Костина “...создание национального рейтингового агентства не решит поставленную задачу. Нам надо искать точки опоры для создания международной системы рейтингов, для того чтобы снижать зависимость от американских рейтинговых агентств, которая беспокоит не только нас, но и Евросоюз, и Китай"8.

По мнению экспертов, “лучше не полностью отказаться от иностранных рейтингов, а снизить их влияние на внутреннюю экономику и внутренние процессы”, например, “в госзаказы и финансирование федеральных программ и госкомпаний ориентировать не только на банки с рейтингом от зарубежных компаний, но и на банки с рейтингом от национальных компаний"9.

Таким образом, во-первых, какие бы прогнозы не давали бы сейчас рейтинговые агентства по России, объективная ситуация, в частности - внешний долг, золото- и валютные резервы РФ от этого не изменятся. Попытка шумихой и суетой, а не реальным положением вещей отпугнуть от России партнёров и инвесторов не выдерживает никакой критики. Во-вторых, в реализацию экономических санкций против России прямо и косвенно вовлечён и Европейский союз. Причём лидеры стран Старого света, несомненно понимают, что в экономическом противостоянии с Россией потери понесут и они сами. Россия, очевидно, уже является страной, с которой необходимо считаться и в экономическом плане. В-третьих, присоединяясь к автору работы ${ }^{10}$, зададим и такие вопросы: с какой силой столкнётся Америка, выпустив на свободу джинна экономических санкций против России? К чему это все приведет? И будет ли это хорошо для самой Америки?

\section{Библиография:}

1. Манойло А.В. Президент Обама и его Континентальная блокада России // NB: Международные отношения. 2014.-№ 4.-C.1-6. DOI: 10.7256/2306-4226.2014.4.11563. URL: http://e-notabene.ru/wi/article_11563.html

2. http://ru.wikinews.org

3. http://finmarket.ru

4. http://www.otr-online.ru

5. www.vestifinance.ru

6. ria.ru

7. itar-tass.com

8. regnum.ru

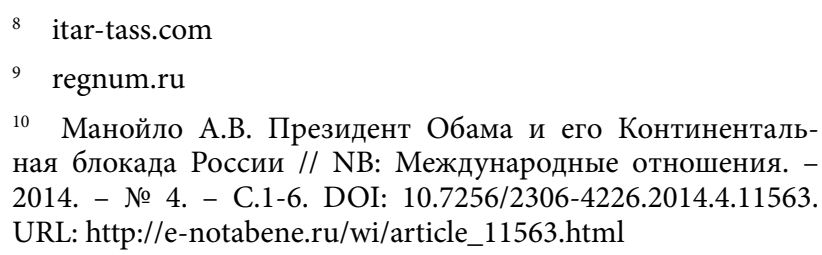
ная блокада России // NB: Международные отношения. 2014. - № 4. - C.1-6. DOI: 10.7256/2306-4226.2014.4.11563. URL: http://e-notabene.ru/wi/article_11563.html 


\section{Международные отношения / International Relations / № 4/2014}

9. cbr.ru

10. www.minfin.ru

11. fitch.com

12. Гушер А.И. Политический кризис на Украине // NB: Международные отношения. - 2014. - 3. - C. 15 - 26. DOI: 10.7256/2306-4226.2014.3.11502. URL: http://www.e-notabene.ru/wi/article_11502.html

13. Бородинов Е.Н. Причины и следствия государственного переворота на Украине // NB: Международные отношения. - 2014. - 3. - С. 36 - 59. DOI: 10.7256/2306-4226.2014.3.11501. URL: http://www.e-notabene.ru/wi/article_11501. html

14. Бочарников И.В. Украинский кризис как элемент пояса стратегического окружения России // NB: Международные отношения. - 2014. - 4. - C. 7 - 32. DOI: 10.7256/2306-4226.2014.4.11617. URL: http://www.e-notabene.ru/wi/ article_11617.html

15. Манойло A.В. Вооруженный мятеж в Украине может стать для России последним тревожным звонком // NB: Международные отношения. - 2014. - 2. - C. 24 - 37. DOI: 10.7256/2306-4226.2014.2.11137. URL: http://www.enotabene.ru/wi/article_11137.html

16. Манойло А.В. Вооруженный мятеж в Украине: волна цветных революций идет на Россию // NB: Международные отношения. - 2014. - 3. - C. 27 - 35. DOI: 10.7256/2306-4226.2014.3.11498. URL: http://www.e-notabene.ru/wi/ article_11498.html

\section{References (transliterated):}

1. Manoilo A.V. Prezident Obama i ego Kontinental'naya blokada Rossii // NB: Mezhdunarodnye otnosheniya. - 2014.-№ 4.-S.1-6. DOI: 10.7256/2306-4226.2014.4.11563. URL: http://e-notabene.ru/wi/article_11563.html

2. http://ru.wikinews.org

3. http://finmarket.ru

4. http://www.otr-online.ru

5. www.vestifinance.ru

6. ria.ru

7. itar-tass.com

8. regnum.ru

9. cbr.ru

10. www.minfin.ru

11. fitch.com

12. Gusher A.I. Politicheskii krizis na Ukraine // NB: Mezhdunarodnye otnosheniya. - 2014. - 3. - C. 15 - 26. DOI: 10.7256/2306-4226.2014.3.11502. URL: http://www.e-notabene.ru/wi/article_11502.html

13. Borodinov E.N. Prichiny i sledstviya gosudarstvennogo perevorota na Ukraine // NB: Mezhdunarodnye otnosheniya. 2014. - 3. - C. 36 - 59. DOI: 10.7256/2306-4226.2014.3.11501. URL: http://www.e-notabene.ru/wi/article_11501.html

14. Bocharnikov I.V. Ukrainskii krizis kak element poyasa strategicheskogo okruzheniya Rossii // NB: Mezhdunarodnye otnosheniya. - 2014. - 4. - C. 7 - 32. DOI: 10.7256/2306-4226.2014.4.11617. URL: http://www.e-notabene.ru/wi/ article_11617.html

15. Manoilo A.V. Vooruzhennyi myatezh v Ukraine mozhet stat' dlya Rossii poslednim trevozhnym zvonkom // NB: Mezhdunarodnye otnosheniya. - 2014. - 2. - C. 24 - 37. DOI: 10.7256/2306-4226.2014.2.11137. URL: http://www.enotabene.ru/wi/article_11137.html

16. Manoilo A.V. Vooruzhennyi myatezh v Ukraine: volna tsvetnykh revolyutsii idet na Rossiyu // NB: Mezhdunarodnye otnosheniya. - 2014. - 3. - C. 27 - 35. DOI: 10.7256/2306-4226.2014.3.11498. URL: http://www.e-notabene.ru/wi/ article_11498.html 